\title{
A 7 year survey of acute hepatitis type B
}

\author{
F BORTOLOTTI, P CADROBBI, A BERTAGgiA, L RUDE, A ALBERTI, \\ AND G REALDI
}

\author{
Istituto di Medicina Clinica, Patologia Medica dell'Università, and Divisione di Malattie Infettive \\ dell'Ospedale Civile, Padua, Italy
}

SUMMARY Epidemiological and clinical features of acute symptomatic hepatitis type B were evaluated in 51 otherwise healthy children and in 13 children receiving immunosuppressive treatment for leukaemia and malignancy, who were admitted to hospital with acute hepatitis B surface antigen ( $\mathrm{HBsAg}$ ) positive hepatitis during a period of 7 years. Blood transfusions, or intimate contacts with asymptomatic HBsAg carriers or with contaminated material during repeated admission to hospital were the possible sources of infection in the immunosuppressed patients, whereas percutaneous exposure was identified as the source in a minority of non-immunosuppressed patients. Features of the acute phase of the illness differed little between the two groups of patients (acute liver failure developed in one patient with leukaemia and in two untreated children). Conversely, chronic evolution was observed in $69 \%$ of immunosuppressed patients but in only $9 \%$ of untreated children and affected only patients born to HBsAg positive mothers (two of four patients) or patients presenting with papular acrodermatitis (both patients).

Acute symptomatic hepatitis type $B$ in infants and children may present the whole clinical spectrum observed in adult patients ${ }^{1}$; the disease may follow a benign course with final recovery; occasionally it may be fulminant either leading to death or eventually resolving. ${ }^{2}$ In some cases it may develop into one of several chronic liver diseases of differing severity, ${ }^{3}$ including cirrhosis. ${ }^{4}$ Factors such as age at onset and administration of immunosuppressive treatment may influence the evolution of the disease. Few studies, however, have investigated the clinical course and outcome of acute hepatitis B in large series of consecutive paediatric patients. ${ }^{5}$ We report the results of a 7 year epidemiological and clinical study of acute hepatitis B in 51 consecutive, otherwise healthy children and in 13 children receiving immunosuppressive treatment for acute leukaemia or malignancy, who were admitted to hospital with symptoms of acute hepatitis B surface antigen (HBsAg) positive hepatitis.

\section{Patients and methods}

Between January 1975 and June 1981155 children, aged three months to 12 years, with no underlying systemic diseases, were admitted to the Department of Infectious Diseases in Padua with acute viral hepatitis. This department serves a district of 600000 inhabitants. Acute viral hepatitis was diagnosed on the basis of clinical history (which permitted exclusion of chronic liver disease or of associated biliary diseases), recent onset of symptoms, signs of liver disease, and fivefold or higher increase in alanineaminotransferase activities above the upper normal value $(<50 \mathrm{IU} / \mathrm{l})$.

Samples of serum were obtained from each patient during the acute phase of the illness and in the follow up period and stored at $-20^{\circ} \mathrm{C}$ until analysis. HBsAg was investigated by commercial radioimmunoassay (Abbott Laboratories). Selected serum samples were assayed for hepatitis B e antigen (HBeAg) and its antibody (anti-HBe) by commercially available radioimmunoassay kits (Abbott Laboratories).

Fifty one (32\%) children ( 26 boys and 25 girls, mean age 6.3 (SD 3.5 ) years) had $\mathrm{HBsAg}$ positive serum during the acute phase of illness. During the same period of observation 13 children (five boys and 8 girls, mean age 7.9 (SD 3.9)) with leukaemia (10 patients) or malignancy (three) were referred from the oncology unit to our department with features of acute hepatitis B. All these patients were receiving, or had recently stopped receiving, immunosuppressive treatment.

In both immunosuppressed and non-immunosuppressed children the probable source of infection was assessed from the history recorded on admission. Repeat controls of liver function tests and of hepatitis $B$ virus markers were performed during the children's stay in hospital and in the follow up period when children were seen every four months for at least one year in the outpatient clinic. Patients still 
showing abnormal transaminase activities at 12 months were considered to have developed chronic hepatitis B. They subsequently underwent liver biopsy by the Menghini technique, with the informed consent of their parents, and were followed up further. Liver histological findings were interpreted according to De Groote et $\mathbf{l}^{6}$ and to Sheuer. ${ }^{7}$

\section{Results}

Epidemiological aspects. During the 7 years of our survey cases of hepatitis B formed a varying proportion of the annual overall number of hepatitis cases. The peak incidence ( $51 \%$ ) occurred in 1975 and was related to an epidemic of acute hepatitis B caused by a contaminated gammaglobulin preparation. The incidence of hepatitis B was $29 \%$ in 1978 and $25 \%$ in 1981. A progressive reduction in the total number of cases of acute hepatitis was also observed during the period of survey with 37 cases seen in 1975, 26 in 1978, and 8 during the first 6 months of 1981. Table 1 shows the age distribution of both immunosuppressed and non-immunosuppressed children with acute hepatitis B and Table 2 summarises the possible sources of infection.

Of the 13 patients with leukaemia or malignancy, 11 had received transfusions with blood from volunteer donors screened for $\mathrm{HBsAg}$ by third generation techniques, and all $13 \mathrm{had}$ been repeatedly admitted to hospital. Conversely, of the 51 nonimmunosuppressed children, only three had been transfused with whole blood and five had received a commercially available preparation of gammaglobulins now known to have been contaminated with HBsAg. ${ }^{8}$ Six children had developed hepatitis during the first 6 months of life; two of them had received transfusions in the neonatal period, and four were born to $\mathrm{HBsAg}$ positive mothers. These four all became $\mathrm{HBsAg}$ positive during the third or fourth month of life; the mother of one developed acute hepatitis type B soon after delivery and was $\mathrm{HBeAg}$ positive at presentation, and the mothers of the other three were asymptomatic HBsAg carriers. (Two of them were anti-HBe positive at delivery, and the third was found to be $\mathrm{HBeAg}$ positive at the time when her child developed acute hepatitis.) Two non-immunosuppressed children had a family

Table 1 Age distribution of 64 children with acute HBs Ag positive hepatitis

\begin{tabular}{llll}
\hline & \multicolumn{3}{l}{ Age (years) } \\
\cline { 2 - 4 } & $0-1$ & $1-5$ & $5-12$ \\
\hline $\begin{array}{l}\text { No (\%) immunosuppressed } \\
\begin{array}{l}(\mathrm{n}=13) \\
\text { No }(\%) \text { non-immunosuppressed } \\
(\mathrm{n}=51)\end{array}\end{array}$ & 0 & $4(31)$ & $9(69)$ \\
\hline
\end{tabular}

Table 2 Possible sources of infection and risk factors in children with acute $\mathrm{HBs} \mathrm{Ag}$ positive hepatitis

\begin{tabular}{lll}
\hline & $\begin{array}{l}\text { Immunosuppressed } \\
\text { children }(n=13)\end{array}$ & $\begin{array}{l}\text { Non-immunosuppressed } \\
\text { children }(\%)(n=51)\end{array}$ \\
\hline $\begin{array}{l}\text { Blood or blood } \\
\text { derivatives }\end{array}$ & 11 & $8(15)$ \\
$\begin{array}{c}\text { Recent admission to } \\
\text { hospital }\end{array}$ & 13 & $6(12)$ \\
$\begin{array}{c}\text { with surgery } \\
\text { Family outbreak of } \\
\text { hepatitis }\end{array}$ & 2 & $6(12)$ \\
$\begin{array}{c}\text { Mother hepatitis B } \\
\text { surface antigen } \\
\text { positive at delivery }\end{array}$ & 0 & $6(12)$ \\
\begin{tabular}{l} 
Unknown \\
\hline
\end{tabular} & 0 & $4(8)$ \\
\hline
\end{tabular}

contact known to be a chronic HBsAg carrier, but serological testing of family members of our patients for $\mathrm{HBsAg}$ was not routinely performed.

Clinical features of the acute phase. All patients were either symptomatic (complaining of anorexia, fatigue, vomiting, and abdominal pain) or had jaundice (Table 3). Extrahepatic manifestations included arthralgia (two cases), urticarioid lesions (five cases), and maculopapular acrodermatitis ( 7 cases), which in two girls aged 3 and 4 years developed the typical features of papular acrodermatitis described by Gianotti, ${ }^{9}$ with adenomegaly and anicteric hepatitis.

No important clinical differences were observed between patients with or without underlying malignancy (Table 3). Three children with symptoms of less than two weeks' duration showed features of acute liver failure on admission, with acute jaundice and encephalopathy. The first patient was a 12 year old girl with leukaemia, who had received transfusions and in whom immunosuppressive treatment had recently been stopped; the second patient was a 3 month old boy born to an asymptomatic anti-HBe positive mother; and the third was a 5 month old girl who had received blood transfusions in the neonatal period.

Evolution of acute hepatitis B. The outcome of acute hepatitis was evaluated in 57 patients who could be followed up for at least one year after clinical onset (Table 4). Of the three patients with acute liver failure, one (the third) died within one week of admission; the other two recovered, with transaminase activities returning to normal 6 to 8 weeks after onset, after receiving symptomatic treatment and exchange transfusions. In the 43 patients who recovered, the clearance of $\mathrm{HBsAg}$ occurred at various intervals, ranging from one to 24 weeks, and preceded the return to normal of transaminase activities in 9 patients only.

Nine immunosuppressed patients with persistently increased transaminase activities remained HBsAg 
Table 3 Clinical and biochemical features of acute hepatitis in the 64 children. (No important differences in the parameters examined were observed between immunosuppressed and non-immunosuppressed children)

\begin{tabular}{|c|c|c|c|c|c|}
\hline & \multicolumn{3}{|c|}{ No (\%) with } & \multicolumn{2}{|l|}{ Mean $(S D)$} \\
\hline & Symptoms & $\begin{array}{l}\text { Extrahepatic } \\
\text { manifestations }\end{array}$ & Jaundice & $\begin{array}{l}\text { Alanineaminotransferase } \\
\text { activity } \\
\text { (normal }<501 U / l)\end{array}$ & $\begin{array}{l}\text { Bilirubin } \\
\text { concentration } \\
\text { (umol/l) }\end{array}$ \\
\hline $\begin{array}{l}\text { Immunosuppressed children } \\
(n=13)\end{array}$ & $10(77)$ & $1(8)$ & $12(92)$ & 1710 (1098) & 202 (139) \\
\hline $\begin{array}{l}\text { Non-immunosuppressed children } \\
(n=51)\end{array}$ & $46(90)$ & $13(25)$ & $45(88)$ & $1148(671)$ & $139(110)$ \\
\hline
\end{tabular}

positive at 12 months, at which time all of them were also found to be $\mathrm{HBeAg}$ positive in serum; liver biopsy specimens were taken in two cases, and both showed features of chronic active hepatitis. Two of the 9 patients subsequently died and three were lost to further follow up. All four patients that could be observed for up to two years remained HBsAg and $\mathrm{HBeAg}$ positive with fluctuating transaminase activities.

Of the four non-immunosuppressed children with evidence of continuing liver disease at 12 months, two were born to $\mathrm{HBeAg}$ positive mothers and the other two had presented with papular acrodermatitis. All four patients remained $\mathrm{HBsAg}$ and $\mathrm{HBeAg}$ positive and were asymptomatic throughout the observation period. Liver biopsy specimens taken during the second year of illness were consistent with chronic active hepatitis in three patients and with chronic lobular hepatits in the fourth.

\section{Discussion}

Acute symptomatic hepatitis B in our region is rarely observed in children, ${ }^{10}$ unlike hepatitis A. The present data seem to indicate a trend toward a further reduction in the incidence of hepatitis $B$, coinciding with the reduction in the total number of cases of acute hepatitis in childhood, as also reported in other European countries. ${ }^{11}$

Table 4 Evolution of acute hepatitis in 57 patients one year after onset

\begin{tabular}{lll}
\hline & $\begin{array}{l}\text { Immunosuppressed } \\
\text { children }(n=13)\end{array}$ & $\begin{array}{l}\text { Non-immunosuppressed } \\
\text { children }(n=44)\end{array}$ \\
\hline $\begin{array}{l}\text { Died of fulminant } \\
\text { hepatitis }\end{array}$ & 0 & $1(2 \%)$ \\
$\begin{array}{l}\text { Healed } \\
\text { Mean (SD) duration of: } \\
\text { Abnormal alanine- }\end{array}$ & $39(0.8)$ & $5.4(3.3)$ \\
$\begin{array}{l}\text { aminotransferase } \\
\text { activity (weeks) } \\
\text { Abnormal bilirubin } \\
\text { concentration } \\
\text { (weeks) }\end{array}$ & $3.7(0 \cdot 9)$ & $4 \cdot 3(1 \cdot 6)$ \\
$\begin{array}{l}\text { Increased alanine- } \\
\text { aminotransferase } \\
\text { activity after }\end{array}$ & $9(69 \%)$ & $4(9 \%)$ \\
12 months & & \\
\hline
\end{tabular}

In our patients, acute hepatitis B was seldom observed in children below one year of age and transmission of infection from mother to neonate occurred in only four children, who developed symptomatic illness within the fourth month of life. Indeed, acute hepatitis seems to be a rare clinical manifestation of infection transmitted in the neonatal period. Shiraki et al..$^{12}$ reported only three cases among 24 children who acquired infection from their HBsAg positive mothers and were born to anti-HBe positive or to $\mathrm{HBeAg}$ negative mothers. Our results not only confirm the possibility that children born to anti-HBe positive mothers may develop overt hepatitis but also indicate that the disease may be severe and, therefore, should be prevented.

In children with no underlying diseases, blood transfusions were found to play a minor epidemiological part and evidence of percutaneous exposure was also rare. In more than half of these patients, therefore, the source of infection remained undefined. Most of them, however, had probably acquired infection from contact with asymptomatic $\mathrm{HBsAg}$ carriers; infection with hepatitis B virus is endemic in Italy.

In the course of our survey a consistent number of children who developed HBsAg positive hepatitis had leukaemia or malignancy and were receiving immunosuppressive treatment. Routine testing for HBsAg had not been performed in these patients before the development of acute hepatitis, and we cannot, therefore, exclude the possibility that, in some cases at least, a reactivation of a latent infection may have occurred after withdrawal of immunosuppressive treatment. ${ }^{13}$ It is well known that children with cancer are at risk of acquiring viral hepatitis due to repeated blood transfusions while receiving immunosuppressive drugs. Indeed, $85 \%$ of this group of patients had received transfusions, although with blood from volunteer donors screened for HBsAg by third generation techniques. We cannot exclude, however, the possibility that contact with asymptomatic carriers or with contaminated material during repeated admissions to hospital may 
have contributed to the spread of infection in this group of patients.

As regards the clinical aspects of the disease, extrahepatic manifestations were almost exclusively represented by cutaneous lesions; papular acrodermatitis, as described by Gianotti, ${ }^{9}$ affected young children; in older patients maculopapular lesions were associated with icteric hepatitis in the absence of adenomegaly. An unfavourable evolution of acute hepatitis was observed in $69 \%$ of immunosuppressed children in agreement with data reported by Malone et al. ${ }^{14}$ Among patients without underlying diseases, fulminant hepatitis developed in two, both below one year of age, and chronic evolution was observed in $9 \%$ of patients, all of whom were below one year of age or had papular acrodermatitis. The persistence of hepatitis B virus infection acquired in the neonatal period has been emphasised in several reports ${ }^{15-17}$ and has been attributed to a state of immunological tolerance due to immaturity of the immune system. In our study the persistence of hepatitis B virus infection was observed only in children born to $\mathrm{HBeAg}$ positive mothers; infants born to anti-HBe positive mothers developed an adequate response to hepatitis B virus. These data might suggest, according to the interpretation proposed by Shiraki et al., ${ }^{12}$ that viral charge may be the determinant in modulating the immune response to hepatitis $B$ virus in neonates and infants. As regards acute hepatitis associated with papular acrodermatitis, Colombo et al. have reported chronic evolution of the illness in about one third of their patients. ${ }^{18}$ Such an unfavourable outcome has been related either to immaturity of the immune system, in younger patients, or to a genetic defect of the immune response. ${ }^{19}$ All four untreated children who developed chronic liver disease were persistently $\mathrm{HBeAg}$ positive in serum and three of them showed features of active hepatitis 12-24 months after the onset of illness. In spite of the severity of liver damage and of the persistence of active virus replication, the long term evolution of the disease in such patients remains unpredictable. In previous reports, we observed that $\mathrm{HBeAg}$ positive children with chronic active hepatitis (with or without a history of acute infection) may spontaneously seroconvert to anti-HBe, with subsequent return to normal of transaminase activities and disappearance of histological features of activity. ${ }^{20} 21$

\section{References}

1 Mowat AP. Viral hepatitis in infancy and childhood. Clin Gastroenterol 1980;9:191-212.

2 Mackenjee MKR, Kiepiela P, Cooper R, Coovadia HM. Clinically important immunological processes in acute and fulminant hepatitis, mainly due to hepatitis B virus. Arch Dis Child 1982;57:277-82.
3 Colombo M, Gerber MA, Vernace SJ, Gianotti F, Paronetto $\mathbf{F}$. Immune response to hepatitis $\mathbf{B}$ virus in children with papular acrodermatitis. Gastroenterology 1977;73:1103-6.

4 Wright R, Perkins JR, Bower BD, Jerrome DW. Cirrhosis associated with the Australia antigen in an infant who acquired hepatitis from her mother. $\mathrm{Br} \mathrm{Med} J$ 1970;iv: 719-21.

5 Dupuy JM, Kostewicz E, Alagille D. Hepatitis B in children. 1. Analysis of 80 cases of acute and chronic hepatitis B. J Pediatr 1978;92:17-20.

${ }^{6}$ De Groote JJ, Desmet VJ, Gedigk P, et al. A classification of chronic hepatitis. Lancet 1968 ;ii:626-8.

7 Scheuer PJ. Liver biopsy interpretation. 3rd ed. London: Ballière Tindall, 1980:102-16.

8 Petrilli FL, Crovari P, De Flora S. Hepatitis B in subjects treated with a drug containing immunoglobulins. J Infect Dis 1977;135:252-8.

9 Gianotti F. Papular acrodermatitis of childhood: an Australia antigen disease. Arch Dis Child 1973;48:794-9.

10 Bortolotti F, Cadrobbi P, Carretta M, Meneghetti F, Pornaro E, Realdi G. Epidemiological aspects on acute viral hepatitis in Northern Italy. Scand J Infect Dis 1982;14:161-4.

11 Skinhøj P, Ibsen KK, Kryger P. Viral hepatitis in Danish children. Arch Dis Child 1982;57:146-8.

12 Shiraki K, Yoshihara N, Sakurai M, Eto T, Kawana T. Acute hepatitis $\mathrm{B}$ in infants born to carrier mothers with the antibody to hepatitis B e antigen. J Pediatr 1980;97: 768-70.

13 Hoofnagle JH, Dusheiko GM, Shaefer DF, Micetich KC, Young RC, Costa J. Reactivation of chronic hepatitis B virus infection by cancer chemotherapy (abstract). Hepatology $1981 ; 1: 517$.

14 Malone W, Novak R. Outcome of hepatitis in children with acute leukemia. Am J Dis Child 1980;134:584-7.

15 Schweitzer IL, Infection of neonates and infants with the hepatitis B virus. Prog Med Virol 1975;20:27-48.

16 Merrill DA, Dubois RS, Kohler PF. Neonatal onset of the hepatitis-associated-antigen carrier state. $N$ Engl J Med 1972;287:1280-2.

17 Skinhøj P. Infection with hepatitis B virus in infancy. A longitudinal study of 8 cases. Arch Dis Child 1978;53: 746-8.

18 Colombo M, Gianotti F, Rumi MG, Cambieri R, Del Ninno E. A clinico-pathological follow-up study of children with hepatitis $\mathrm{B}$ and papular acrodermatitis. In: Bartoli E, Chiandussi L, Sherlock S, eds. Systemic effects of HBs Ag immune complexes. Padova: Piccin Medical Books, 1981:225-39.

19 Toda G, Maeda H, Ishimaru Y, et al. HLA typing in the infants with persistent $\mathrm{HBs}$ antigenemia following Gianotti's infantile papular acrodermatitis (abstract). Gastroenterology 1981;79:1128-31.

20 Bortolotti F, Cadrobbi P, Crivellaro C, Bertaggia A, Alberti A, Realdi G. Chronic hepatitis type B in childhood: longitudinal study of 35 cases. Gut $1981 ; 22$ : 499-504.

21 Trevisan A, Cadrobbi P, Crivellaro C, Bortolotti F, Rugge M, Realdi G. Virologic features of chronic hepatitis B virus infection in childhood. J Pediatr 1982; 100:366-72.

Correspondence to Professor G Realdi, Instituto di Medicina Clinica dell' Università di Padova, Via Giustiniani 2, 35100 Padova, Italy.

Received 1 August 1983 